\title{
RELATIONSHIP BETWEEN PASSIVE IMMUNITY AND MORBIDITY AND WEIGHT GAIN IN DAIRY CATTLE
}

\author{
RELAÇÃO ENTRE IMUNIDADE PASSIVA E MORBIDADE E \\ GANHO DE PESO EM BOVINOS LEITEIROS
}

\author{
Mauro Pires Moraes ${ }^{1}$ Rudi Weiblen $^{2}$ Marlon Cesar Rebelatto $^{3}$ Adriana Moraes da Silva $^{4}$
}

\section{SUMMARY}

Serum samples from 87 calves from a dairy herd in Southern Brazil were collected to determine the levels of passive transfer and its relationship to morbidity and mean daily weight gain $(M D G)$. Serum immunoglobulin (Ig) levels were measured by the zinc sulfate turbidity test at 24 hours of age in the calves. The average serum Ig level was $11.40 \mathrm{~g} / \ell$. Fourteen out of 87 calves $(16.1 \%)$ showed serum Ig levels one standard deviation below the mean $(4.59 \mathrm{~g} / \ell)$ and were considered as having failure of passive immunity transfer (FPT). The occurrence of diarrhea from birth to weaning was higher in the FPT group (100\%) than the normal group $(90.7 \%)$ but the difference was not significant. The occurrence of signs of respiratory disease was similar in both groups (35.7\% for FPT and 36.9\% for the normal group). The mean daily gain from birth to 13-16 months of age in the FPT group was significantly $(P>0.05)$ lower than in the group with normal serum Ig levels. The difference in $M D G$ from birth to weaning between the groups was not significant. These results demonstrate the importance of passive immunity in cattle, and also provide regional parameters for the evaluation of FPT in cattle.

Key words: passive immunity, calves, morbidity.

\section{RESUMO}

Com objetivo de determinar a eficiência da transferência da imunidade passiva e a relação com morbidade e ganho médio de peso diário (GMD) em condições e regionais, foram utilizadas amostras de soro de 87 fêmeas da raça holandesa e de suas respectivas terneiras, mantidas em uma propriedade da região central do estado do Rio Grande do Sul. Nas vacas, o nível de imunoglobulinas (Igs) séricas foi determinado pela técnica de turvação pelo sulfato de zinco, 28 dias antes do parto e, nas terneiras, às 24 horas de vida, após fornecimento de colostro ad

\begin{abstract}
libitum desde o nascimento. A média de imunoglobulinas séricas foi de 24,22 e 11,40g/ $\ell$, nas vacas e terneiras respectivamente. Os níveis séricos de imunoglobulinas das terneiras demonstraram baixa correlação $(R=0,14)$ com os níveis de suas genitoras. Das 87 terneiras, 14 (16,10\%) apresentaram níveis de Igs inferiores a um desvio padrão abaixo da média $(4,59 \mathrm{~g} / \ell)$ e foram consideradas com falha de transferência de imunidade passiva (FTP). No período do nascimento até o desmame, foi observada maior ocorrência de diarréia no grupo de animais com FTP (100\%) comparado aos demais com aporte normal de Igs (90,7\%), porém a diferença não foi significativa entre os grupos. A prevalência de sinais clínicos de doenças respiratórias também foi semelhante nos dois grupos (35,70\% e 36,90\% respectivamente). Ao analisar-se o GMD do nascimento até os 13-16 meses de idade entre os grupos, observou-se que os animais com FTP apresentaram esse índice menor que os demais $(P<0,05)$, o que não pode ser observado no período do nascimento até o desmame. Os resultados demonstram a importância da imunidade passiva em bovinos, além disso, fornecem parâmetros regionais para sua avaliação.
\end{abstract}

Palavras-chave: imunidade passiva, morbidade, bovino.

\section{INTRODUCTION}

Calves are born hypo or agammaglobulinemic due to the type of bovine placentation (STOTT et al., 1976). For this reason, passive immunity acquired through colostrum ingestion is especially relevant for neonatal immunity. The ability of newborn calves to survive during the perinatal period depends on the appropriate exposure of the dam to environmental agents to which the calves will be exposed and on colostrum ingestion

\footnotetext{
${ }^{1}$ DVM, Assistant Professor, MSc. Departmento de Medicina Veterinária, Universidade Federal de Viçosa.

${ }^{2}$ DVM, Professor, MSc. PhD, Departmento de Medicina Veterinária Preventiva, Microbiologia e Parasitologia Universidade Federal de Santa Maria, 97105-900, Santa Maria, RS, Brasil, E-mail: rudi@ccr.ufsm.br Author for correspondence.

${ }^{3}$ DVM, MSc, Purdue University, West Lafayette, - USA.

${ }^{4}$ DVM, MSc, União Pioneira de Integração Social, Brasília. 
and absorption of immunoglobulins in the first 24 hours of life (OSBURN et al., 1974).

The importance of colostrum for neonates was observed in 1905 even before its specific components had been determined (GARRY et al., 1993). From that first description, a wealth of research has been accomplished with different approaches. They have been reviewed on the aspects of protection against infectious agents (BRENNER, 1991), as well as on the factors interfering with passive transfer of Ig to calves (REBELATTO \& WEIBLEN, 1992). Examples of these factors are environmental factors such as temperature (STOTT et al., 1976), season (DONOVAN et al., 1986; HANCOCK, 1985), management (ROY, 1990), and sanitary conditions (BUSH \& STALEY, 1980). Host factors such as postnatal respiratory acidosis (BESSER $\boldsymbol{e t} \boldsymbol{a l} ., 1990)$ or prematurity (JOHNSTON \& STEWART, 1986) may also affect the absorption of Ig. Factors related to the genitor such as the transfer of Ig from the bloodstream to mammary secretions (WINGER et al.,1995), specific infections (HÜBNER, 1996; LOPEZ et al.,1988), mastitis (PERINO $\boldsymbol{e t}$ al., 1995) or vaccination (BOLAND $\boldsymbol{e t}$ al., 1995; SAIF \& SMITH, 1985) also interfere with passive immunity.

The influence of so many factors predisposes calves to FPT (HANCOCK, 1985). FPT describes the circumstances in which a neonate does not absorb sufficient colostral immunoglobulins (Ig). According to PERINO et al. (1993), FPT is a serious and present problem in calves and although some of the factors that interfere with passive transfer are well known, FPT is still an obstacle to productivity. Several researchers have suggested threshold levels of serum Ig that could be considered adequate for the maintenance of health and growth performance in calves, but these concentrations are not universally accepted yet (CALDOW et al., 1988; ROBISON et al., 1988). The diagnosis of FPT is not well defined and the established values for its diagnosis may lead to incorrect decisions (GARRY et al., 1993).

Weight gain has also been associated with passive immunity in calves. NOCEK et al. (1984) and QUIGLEY et al. (1995) showed that inadequate amounts of colostrum administered to calves resulted in higher mortality rates, more severe diarrhea, and lower weight gain in affected calves. ROBISON et al. (1988) observed higher mortality rates and lower weight gain in calves with low serum Ig concentrations. However, the lower weight gain in FPT calves may be related to the higher morbidity observed in these calves rather than to the serum Ig levels (WITTUM \& PERINO, 1995). The weight gain performance in dairy cattle is of utmost importance since it directly influences the age at first calving (WITTUM \& PERINO, 1995). However, other researchers have not been able to demonstrate such consequences of FPT (CALDOW et al., 1988; RAJALA \& CASTRÉN, 1995; REA et al., 1996; TOOD \& WHITE, 1995).

The objectives of this study were to evaluate the serum Ig levels in newborn calves from a dairy herd in southern of Brazil and to relate these levels to morbidity and weight gain in the first 16 months of life. Moreover, this study aimed to obtain regional parameters for the evaluation of failure of passive immunoglobulin transfer in cattle, since most of such studies were carried out in countries with different environmental, genetic, and technologic conditions than in southern Brazil.

\section{MATERIALS AND METHODS}

Eighty-seven female calves from a dairy herd in the state of Rio Grande do Sul, Brazil were used in the study. The age of the dams ranged from 2.5 to 8 years. The dams were maintained in the pasture during the gestation period and in isolated pens after calving where they received hay or silage supplemented with grains. The calving period for the calves used in this study was from March to June 1994. The calves were removed from their dams right after parturition and housed in individual hutches. They were fed a pool of colostrum from different cows during the first 2 days of life which was subsequently replaced by milk and after that by hay and concentrate, gradually. Weaning was carried out at approximately 2 months of age, when the calves were moved to small pastures. The calves were observed by a veterinarian on a daily basis until the calves were 6 weeks old and morbidity data of diarrhea and respiratory disease were recorded. In addition, the calves were weighed at birth, weaning, and at 13 to 16 months of age.

Blood samples were collected by jugular venipuncture $24 \mathrm{~h}$ after calves received colostrum. Serum was obtained by centrifugation within $24 \mathrm{~h}$ of collection and stored at $-20^{\circ} \mathrm{C}$ until analyzed. Serum samples were assayed for total immunoglobulin (Ig) levels by the zinc sulfate turbidity test as described by PFEIFFER et al. (1977), with some modifications. A solution of zinc sulfate ${ }^{\mathrm{a}}(208 \mathrm{mg}$ of $\mathrm{ZnSO}_{4}$ added to 11 of distilled water that had been boiled to remove carbon dioxide) was prepared in distilled water. One hundred microliters of each serum sample was mixed with $6 \mathrm{ml}$ of $\mathrm{ZnSO}_{4}$ solution and incubated for $1 \mathrm{~h}$ at room temperature. Then turbidity (absorbance) was read at $485 \mathrm{~nm}$ in a 
spectrophotometer $^{\mathrm{b}}$. The amount of $\mathrm{Ig}$ in $\mathrm{g} / \ell$ was calculated from absorbance values using a standard curve obtained with bovine fetal serum (BFS) with a known concentration of bovine gammaglobulin ${ }^{\mathrm{c}}$ prepared at different concentrations $(0,5,15,25$ and $35 \mathrm{~g} / \ell$ ).

The effect of hemolysis on turbidity was determined by adding bovine erythrocytes to different concentrations of BFS. Hemolysis was produced by $\mathrm{ZnSO}_{4}$ solution freezing and thawing the sample repeatedly. The correction factor for hemolysis was calculated from the increase in $\mathrm{ZnSO}_{4}$ turbidity caused by hemolysis compared to the absorbance at 540nm of serum samples diluted in phosphate buffered saline (PBS) as described (PFEIFFER et al., 1977).

Mean daily weight gain (MDG) was the variable used to determine the growth performance of calves. MDG was calculated by the weight difference from the beginning to the end of the period divided by the number of days in the period. Two periods were determined: MDG1, from birth to weaning and, MDG2, from birth to 13-16 months of age. Calves were considered as having FPT when their serum Ig levels were below one standard deviation below the mean at $24 \mathrm{~h}$ of life. A $\chi^{2}$ analysis was used to evaluate the influence of passive immunity on morbidity and mortality. A $t$ test was used to evaluate the influence of passive immunity on MDG.

\section{RESULTS AND DISCUSSION}

Serum Ig concentrations in newborn calves vary considerably among animals (WITTUM \& PERINO, 1995). In this study, the mean serum Ig level obtained from 87 calves at $24 \mathrm{~h}$ of age was $11.40 \mathrm{~g} / \ell$, with a standard deviation of 6.81 (table 1). According to MORAES et al. (1997), the zinc sulfate turbidity test has a good correlation $(r=0.91)$ with serum electrophoresis. Despite the high variation among animals, serum Ig levels may be good indicators of the passive immunity status on a population basis. The mean serum Ig levels observed in this study were consistent with those observed by NOCEK et al. (1984) in animals given colostrum only once during the first 24 hours, but were lower than the levels observed in animals given colostrum ad libidum. Prematurity (JOHNSTON \& STEWART, 1986) and individual differences (RAJALA \& CASTRÉN, 1995) are another conditions that may contribute to variation observed among animals.
Table 1 - Passive immunity and serum immunoglobulin levels at $24 \mathrm{~h}$ of life in Holstein calves from a dairy herd in southern Brazil.

Condition $^{1}$ Number (\%) Mean Serum Ig $(\mathrm{g} / \ell)^{2}$ Standard Deviation

\begin{tabular}{lccc}
\hline & & & \\
Normal & $73(83.9)$ & 13.19 & 6.70 \\
FPT & $14(16.1)$ & 2.67 & 1.20 \\
\hline Total & $87(100.0)$ & 11.40 & 6.81 \\
\hline
\end{tabular}

${ }^{1}$ Calves with serum Ig levels higher than $4.59 \mathrm{~g} / \mathrm{l}$ were considered normal while those with serum Ig levels lower than $4.59 \mathrm{~g} / 1$ were considered as having failure of passive immunoglobulin tranfer (FPT).

The influence of the age of the calf at first feeding on passive transfer was studied by TOOD \& WHYTE (1995). They showed that different groups of animals fed colostrum only once from 2 to $8 \mathrm{~h}$ after birth had similar mean serum Ig levels and were consistent with the results shown in table 1 . BOYD (1987) demonstrated that the amount of $\mathrm{Ig}$ absorbed depends on the amount of colostrum received and decreases as the animals age. Another factor that could determine a decrease in colostral Ig absorption is postnatal respiratory acidosis (BESSER $\boldsymbol{e}$ t al., 1990). BUSH \& STALEY (1980) concluded that the total amount of $\mathrm{Ig}$ ingested determines a higher absorption of Ig than the amount of colostrum ingested. This conclusion was consistent with studies by STOTT et al. (1979a) who showed that the concentration of Ig in colostrum did not influence the rate of Ig absorption. The influence of suckling on the absorption of colostral Ig was studied by STOTT et al. (1979b). They observed that calves that received colostrum in a bottle had higher absorption than calves that received colostrum by natural suckling. The mean serum Ig level observed in our study (table 1) was similar to that obtained by HANCOCK (1985) during winter and spring but was lower than the mean observed in the summer and fall. DONOVAN et al. (1986) observed seasonal effects on colostrum absorption in 2,103 calves born in Florida, United States during a two-year period. February and March were the months with highest passive immunoglobulin transfer, while July and August were the months with lowest Ig absorption rates. These differences were explained by STOTT et al. (1976) as being a direct function of body and environmental temperature on the absorption of Ig.

The great variability on the serum $\mathrm{Ig}$ concentrations found in passive transfer studies, influenced by external factors (REBELATTO \& 
Table 2 - Number of cases of diarrhea, respiratory signs and mortality in calves with normal passive immunoglobulin transfer and with failure of passive transfer (FPT).

Condition $^{1}$ Total Diarrhea No. (\%) Respiratory Signs No. (\%)

\begin{tabular}{lccc}
\hline & & & \\
Normal & 73 & $66(90.4)$ & $27(36.9)$ \\
FPT & 14 & $14(100.0)$ & $05(35.7)$ \\
\hline Total & 87 & $80(92.0)$ & $32(36.8)$ \\
\hline
\end{tabular}

${ }^{1}$ Calves with serum Ig levels higher than $4.59 \mathrm{~g} / \mathrm{l}$ were considered normal while those with serum Ig levels lower than $4.59 \mathrm{~g} / \mathrm{l}$ were considered as having FPT.

WEIBLEN, 1992), makes it difficult to determine and define failure of passive immunoglobulin transfer (FPT). The serum Ig concentration below which a calf was considered as having FPT varies among researchers. The values ranged from 5 to $12 \mathrm{~g} / \ell$ serum (DAVIDSON et al., 1981; HANCOCK, 1985; CALDOW et al., 1988; RAJALA \& CASTRÉN, 1995; ROBISON et al., 1988; BOLAND et al., 1995; PERINO et al., 1995; WITTUM \& PERINO, 1995). The criterion used in our study was also used by McGUIRE et al. (1976). However, these parameters should be used as a regional reference (or even only for a particular farm) since the concentration of serum Ig is only one of multiple factors determining passive immunity in cattle, as suggested by GARRY et al., (1993).

In a study, the proportion of animals with FPT was lower than in some reports (ROBISON $\boldsymbol{e t}$ al., 1988; WITTUM \& PERINO, 1995) and similar to other studies (BOLAND et al., 1995; McGUIRE et al., 1976; PERINO et al., 1995). However, such comparisons have limited value due to differences in experimental design between studies, different populations, environmental and management conditions. This large variability has also been noted by HANCOCK (1985) who studied FPT in 19 herds, and by WHITE \& ANDREWS (1986) who analyzed different studies from the United States and United Kingdom.

The morbidity rate due to diarrhea was $90.8 \%$ in calves from birth to six weeks of age and is shown in table 2. This rate was calculated as described by SCHWABE $\boldsymbol{e t}$ al. (1977) and is very high compared to other studies. BOLAND et al. (1995) described a $40 \%$ morbidity rate in calves born to dams nonvaccinated for rotavirus, coronavirus, Clostridium perfringes type C, and $\boldsymbol{E}$. coli, and $17 \%$ in calves born to vaccinated dams.
CALDOW et al. (1988) found $12.5 \%$ of calves with enteric disease, while WITTUM \& PERINO (1995) observed a $19.8 \%$ morbidity rate from birth to weaning

Despite previous evidence that morbidity is more frequently associated with calves with low serum Ig levels (IRWIN, 1974; OXENDER et al., 1973; LOPEZ et al., 1988; WITTUM \& PERINO, 1995), no significant differences were found between FPT and normal calves in the present study (table 2). QUIGLEY et al. (1995) suggested that the difficulty in finding a relationship between diarrhea and passive immunity is due to the large number and variety of pathogens found in experimental animals under different management conditions. BOLAND et al. (1995) found a $40 \%$ reduction in cases of diarrhea in calves born to vaccinated dams compared to nonvaccinated dams. However, they could not find a correlation between an increase in serum $\mathrm{Ig}$ levels and a decrease in clinical signs of diarrhea. Studies by SAIF \& SMITH, (1985) suggested that protection against rotavirus was not consistently associated with passive immunity. The results of our study were also in agreement with other studies (TOOD \& WHITE, 1995; RAJALA \& CASTRÉN, 1995; CALDOW et al., 1988) where no association could be found between passive immunity status and morbidity attributable to diarrhea. It is likely that Igs are more effective in preventing diarrhea when acting locally in the gastrointestinal tract and this may explain, as suggested by CALDOW et al. (1988), the lack of significant relationship between serum Ig levels and morbidity by diarrhea in several studies. For this reason, it has been suggested that colostrum should be given continually even after the closure of intestinal permeability to colostral Igs (WOODE, 1978). Therefore, it is apparent that variables other than the efficacy of passive transfer determined the occurrence of diarrhea in the calves of this study. The lack of significant relationship between passive transfer and morbidity by diarrhea may have resulted from the high frequency of diarrhea in the study calves (table 2).

Passive immune status at 24 hours was also not associated with respiratory tract morbidity in the study calves (table 2). These results are in contrast to those by DAVIDSON et al. (1981), who found a strong association between low serum IgG levels and deaths caused by respiratory disease. Our results, on the other hand, are consistent with those of CALDOW et al. (1988) who observed a $24.8 \%$ incidence of respiratory disease in animals with plasma IgG1 levels lower than $5 \mathrm{~g} / \ell$ which was not significantly different from animals with higher 
plasma IgG1 levels. The differences observed among these studies may have resulted from the criteria used to define cases of respiratory disease in calves. While DAVIDSON et al. (1981) used cases of respiratory disease resulting in mortality, CALDOW et al. (1988) reported only cases that required treatment.

The results presented in figure 1 indicate that calves that had FPT gained less weight than those with normal passive immunity $(\mathrm{P}<0.05)$, in the period from birth to 13 to 16 months of age. These results are in agreement with those of ROBISON $\boldsymbol{e t}$ al. (1988) who observed differences in weight gain until animals were 180 days-old. They also observed that the largest difference occurred from 70 to 105 days of age, corresponding to the weaning period. On the other hand, the difference in MDG between FPT and normal calves was not significant in the birth-to-weaning period (figure 1). This is in agreement with studies by NOCEK et $\boldsymbol{a l}$. (1984) who could not find differences in weight gain in calves with FPT compared to calves with high serum Ig levels at 45 days of age. However, they observed that gain weight was lower in animals receiving milk substitutes. ROBISON et al. (1988) observed that passive immunity did not contribute significantly to MDG in calves from birth to weaning. QUIGLEY $\boldsymbol{e t}$ al. (1995) attributed differences in MDG rather to the management conditions of the farm than to the passive immune status of the animals.

CALDOW et al. (1988) and WITTUM \& PERINO (1995) observed that animals that had FPT gained less weight than animals with adequate passive transfer, but they considered this to be an indirect effect of the increased morbidity observed in animals with FPT. However, BOLAND et al. (1995) could not find differences in MDG even in groups of animals with higher morbidity rates due to diarrhea. In the present study it was also not possible to find a relationship between weight gain and morbidity.

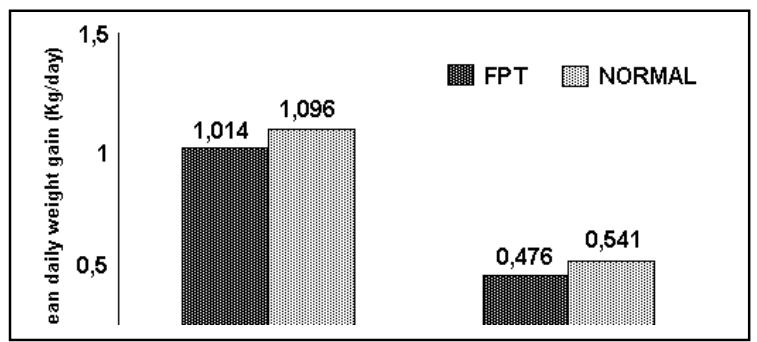

Figure 1 - Mean daily weight gain in calves with normal passive immunoglobulin transfer and with failure of passive transfer (FPT)from birth to weaning (GMD1) and from birth to 13 - 16 months of age (GMD2).

* Difference $(\mathrm{P}<0.05)$
The results obtained in the present study indicate that serum Ig concentrations in calves at 24 hours of life vary considerably. Such individual variations have been frequently reported in the literature and may have been responsible for the inconsistencies in determining an association between passive immunity and mortality, morbidity, and weight gain. It indicates that factors other than passive immunity influence productivity and herd health. In herds with a high morbidity rate it may not be possible to demonstrate an association between passive immunity and the occurrence of disease. In addition, if mortality in a particular herd is low, it may not be possible to find such association either. The determination of threshold values for the diagnosis of FPT, needs to be done at a regional level, or even at a farm level. Animals with FPT may show a lower weight gain. However, further research is needed to clarify the conflicting information regarding passive immunity, disease and productivity.

\section{SOURCES AND MANUFACTURES}

${ }^{a}$ ZINC SULFATE P.A. - VETEC Química Fina, Rio de Janeiro, RJ, BRAZIL.

b SPECTROPHOTOMETER E-225D - CELM Companhia Equipadora de Laboratórios Modernos, Barneri, SP, BRAZIL. ${ }^{c} \gamma$-GLOBULINS BOVINE - SIGMA Chemical Company, St. Louis, Missouri, USA.

\section{REFERENCES}

BESSER, T.E., SZENCI, O., GAY, C.C. Decreased colostral immunoglobulins absorption in calves with postnatal respiratory acidosis. J Am Vet Med Assoc, v.196, p.1239-1243, 1990.

BOLAND, W., CORTESE, V., STEFFEN, D. Interactions between vaccination, failure of passive transfer, and diarrhea in beef calves. Agri-pract, v.16, p.25-28, 1995.

BOYD, J.W. Computer model of the absorption and distribution of colostral immunoglobulins in the newborn calf. Res Vet Sci, v.43, p.291-296, 1987

BRENNER, J. Passive lactogenic immunity in calves: a review. Isr J Vet Med, v.46, p.1-12, 1991.

BUSH, L.J., STALEY, T.E. Absorption of colostral immunoglobulins by newborn dairy calves. J Dairy Sci, v.63, p.672-680, 1980

CALDOW, G.L., WHITE, D.G., KELSEY, M., et al.. Relationship of calf antibody status to disease and performance. Vet Rec, v.122, p.63-65, 1988.

DAVIDSON, J.A., YANCEY, S.P., CAMPBELL, S.G., $\boldsymbol{e} \boldsymbol{t}$ al.. Relationship between serum immunoglobulin values and incidence of respiratory disease in calves. J Am Vet Med Assoc, v.179, p.708-710, 1981 
DONOVAN, G.A., BADINGA, L., COLLIER, R.J, et al.. Factors influencing passive transfer in dairy calves. J Dairy Sci, v.69, p.754-759, 1986.

GARRY, F., ALDRIDGE, B., ADAMS, R. Role of colostral transfer in neonatal calf management: current concepts in diagnosis. Compend Contin Educ Pract Vet, v.15, p.11671174,1993

HANCOCK, D.D. Assessing efficiency of passive immune transfer in dairy herds. J Dairy Sci, v.68, p.163-183, 1985.

HÜBNER, S.O. Infecção intra-uterina e evolução da imunidade passiva contra o vírus da leucose bovina, parvovírus bovino e herpesvírus bovino tipo1. Santa Maria, 1996. 82p. Dissertação ( Mestrado em Medicina Veterinária) - Programa de Pós-graduação em Medicina Veterinária, Universidade Federal de Santa Maria, 1996.

IRWIN, V.C.R. Incidence of disease in colostrum-deprived calves. Vet Rec, v.94, p.105-106, 1974.

JOHNSTON, N.E., STEWART, J.A. The effect of glucocorticoids and prematurity on absorption of colostral immunoglobulins in the calf. Aust Vet J, v.63,p.191-192, 1986.

LOPEZ, J.W., ALLEN, S.D., MITCHELL, J., et al.. Rotavirus and Cryptosporidium shedding in dairy calf faeces and its relationship to colostrum immune transfer. J Dairy Sci, v.71, p.1288-1294, 1988.

McGUIRE, T.C., PFEIFFER, N.E., WEIKEL, J.M., et al Failure of colostral immunoglobulin transfer in calves dying from infectious disease. J Am Vet Med Assoc, v.169, p.713718, 1976.

MORAES, M.P., WEIBLEN, R., SILVA, A.M., et al.. Evolution of passive immunity in Holstein heifers. Ciência Rural, v.27, p.435-440, 1997.

NOCEK, J.E., BRAUND, D.G., WARNER, R.G. Influence of neonatal colostrum administration immunoglobulin, and continued feeding of colostrum and calf gain, health, and serum protein. J Dairy Sci, v.67, p.319-333, 1984.

OSBURN, B.I., STABENFELDT, G.H., ARDANS, A.A., $\boldsymbol{e} \boldsymbol{t}$ al. Perinatal immunity in calves. J Am Vet Med Assoc, v.164, p.295-298, 1974.

OXENDER, W.D., NEWMAN, L.E., MORROW, D.A. Factors influencing dairy calf mortality in Michigan. J Am Vet Med Assoc, v.162, p.458-460, 1973.

PERINO, L.J., SUTHERLAND, R.J., WOOLEN, N.E. Determination of passive immunity in calves. Agric Res Service, v.71, p.176-179, 1993

PERINO, L.J., WITTUM, T.E., ROSS, G.S. Effects of various risk factors on plasma protein and serum immunoglobulin concentrations of calves at post partum hours 10 and 24. Am J Vet Res, v.56, p.1144-1148, 1995

PFEIFFER, N.E., McGUIRE, T.C., BENDEL, R.B., et al. Quantitation of bovine immunoglobulins: comparison of single radial immunodiffusion, zinc sulfate turbidity, serum electrophoresis, and refractometer methods. Am J Vet Res, v.38, p.693-698, 1977

QUIGLEY, J.D., MARTIN, K.R., BEMIS, D.A. et al. Effects of housing and colostrum feeding on serum immunoglobulins, growth, and fecal scores of Jersey calves. J Dairy Sci, v.78, p.893-901, 1995.

RAJALA, P., CASTRÉN, H. Serum immunoglobulin concentrations and health of dairy calves in two management systems from birth to 12 weeks age. J Dairy Sci, v.78, p.2737-2744, 1995.

REA D.E, TYLER J.W., HANCOCK D.D., et al. Prediction of calf mortality by use of tests for passive transfer of colostral immunoglobulin. J Am Vet Med Assoc, v.208, p.2047, 1996.

REBELATTO, M. C., WEIBLEN, R. Importância da imunidade passiva para o terneiro. Ciência Rural, v.22, n.1, p.109-118, 1992.

ROBISON, J. D., STOTT, G.H., DENISE S.K. Effects of passive immunity on growth and survival in the dairy heifer. J Dairy Sci, v.71, p.1283-1287, 1988.

ROY, J.H.B. The calf - management of health. 5 ed. London : Butterworths, 1990. Cap. 2: Immunity to disease: p.17-52.

SAIF, L.J., SMITH K.L. Enteric viral infections of calves and passive immunity. J Dairy Sci, v.68, p.206-228, 1985.

SCHWABE, C.W., RIEMANN, H.P., FRANTI, C.E Epidemiology in veterinary practice. Philadelphia: Lea \& Febiger, 1977. 303p.

STOTT, G.H., WIERSMA, F., MENEFEE, B. E., et al.. Influence of environment on passive immunity in calves. J Dairy Sci, v.59, p.1306-1310, 1976.

STOTT,.G.H., MARX, D.B., MENEFEE, B.E., et al.. Colostral immunoglobulin transfer in calves. II. Rate of absorption. J Dairy Sci, v.62, p.1766-1773, 1979a.

STOTT, .G.H., MARX, D.B., MENEFEE, B.E, et al.. Colostral immunoglobulin transfer in calves. IV. Effect of suckling. J Dairy Sci, v.62, p.1908-1913, 1979b.

TOOD, A. G., WHYTE, P.B.D. The effect of delays on feeding colostrum and the relationship between immunoglobulin concentration in the serum of neonatal calves and their rates of growth. Aust Vet J, v.72, p.415-417, 1995.

WHITE, D.G., ANDREWS, A. H. Adequate concentrations of circulating colostral proteins for market calves. Vet Rec, v.119, p.112-114, 1986.

WINGER, K., GAY, C.C., BESSER, T.E. Immunoglobulin G1 transfer into induced mammary secretions: the effect of dexametasone. J Dairy Sci, v.78, p.1306-1309, 1995.

WITTUM, T.E., PERINO, L.J. Passive immune status at postpartum hour 24 and long-term health and performance of calves. Am J Vet Res, v.56, p.1149-1154, 1995.

WOODE , G.N. Epizootiology of bovine rotavirus infection. Vet Rec, v.103, p.44-46, 1978. 